(on p. 27) which seems like a slip, namely, "the opinionated man, tenacious and dogmatic . ..". Surely this is, in part, a tautology if the Greek $\delta \delta \xi_{\alpha}$ is accorded its usual rendering.

The proof-reading must have been exemplary, and the format is attractive. This is a book to be bought rather than borrowed. It will not find easy acceptance, nor make rapid converts. But if neglected, it may well be at our peril.

F. I. G. RAwLINS

\section{PURE AND APPLIED CHEMISTRY OF STARCH}

Chemistry and Industry of Starch

Edited by Dr. Ralph W. Kerr. Second edition, revised and enlarged. Pp. xii +719 . (New York: Academic Press, Inc., 1950.) 11.50 dollars.

$\mathrm{B}$ EFORE the first edition of this book was published in 1944, more than four thousand papers had appeared on the subject of starch, and the late H. E. Armstrong once used the expression "the tragedy of starch" in reference to the subject. Since 1939 matters have changed, and so far as chemical structure is concerned a much clearer picture is now possible, although one would welcome further advances in the physical properties and the industrial applications of starch and its products.

This excellent book-now in its second edition and greatly enlarged-is described as "Edited by Ralph W. Kerr", and it is true that his co-authors have contributed a number of chapters, but it is largely the author's own work. In many parts, particularly those in which he is dealing with scientific aspects of the subject and in which his own investigations have contributed to what is known, the author writes critically, with a command of his subject and adequate familiarity with the work of others.

The book is in five sections, of which the first deals with the starch granule and the chief varieties of starch. Section 2, comprising five chapters, is concerned with the manufacture of various types of native and modified starches, the chapter on corn starch having been rewritten for this edition. Section 3 comprises two chapters on the physical properties (by Dexter French) and the chemical properties of starch, both critically written and including developments, almost up to the time of writing, in the synthesis of starch components.

Section 4 deals with reactions and includes chapters respectively on the hydrogen bond as a basis for interpreting certain starch properties and on dextrinization, both by G. V. Caesar, oxidation (by J. M. Newton and G. T. Peckham), the manufacture of dextrins and acid hydrolysis of starch, and a long one (by Ed. F. Degering) on derivatives, with more than three hundred references. Most of these chapters have been enlarged in the present edition and give clear evidence of the authors' practical experience of the matters under discussion. The amylases are excellently reviewed by $\mathrm{E}$. Kneen, and modification of starch by enzymes treated by G. M. Severson. A chapter on miscellaneous reactions has been greatly enlarged in this edition to include new work on the interaction with iodine.

Section 5 comprises one chapter on the analysis of starch (this is a new chapter) and six on its uses in industry - for example, modern fermentation products (by L. M. Christensen), food, paper, textiles, adhesives (by A. Frieden) and miscellaneous uses. The chapter on starch in fermentation industries has been enlarged, while the practical, technical and commercial aspects are well treated in the various chapters on the uses and applications of starch.

There are pages of references to each chapter of the book, and complete author and subject indexes and numerous illustrations, both photographic and diagrammatic. The photographic illustrations are better finished than in the first edition. An error in many of the page headings in the chapters on the physical and chemical properties of starch reverses these titles. The book will be invaluable to the pure scientist and the technologist.

R. H. HOPKINS

\section{THE ELECTRON MICROSCOPE IN METALLURGY}

Metallurgical Applications of the Electron Microscope

A Symposium held at the Royal Institution, London, on 16 November 1949, and organized by the Institute of Metals in association with the Chemical Society, the Faraday Society, the Institute of Physics, the Institution of Electrical Engineers, the Iron and Steel Institute, the Physical Society, and the Royal Microscopical Society. (Institute of Metals Monograph and Report Series, No. 8.) Pp. vi $164+50$ plates. (London: Institute of Metals, 1950.) 21s.

$\mathrm{M}$ AGNIFICATIONS beyond the range of the ordinary microscope are of metallurgical importance in many directions. Examples are to be found in the nature of the irresolvable constituents of hardened and tempered steels, the mechanism of age-hardening, the nature of the crystal boundaries and precipitations of ultra-microscopic films there. Further, the fundamental nature of plastic deformation, the real nature of slip bands, and the size of the fragments into which metallic crystals are broken down, all demand a technique beyond the range of normal microscopic vision.

Therefore, the symposium on the "Metallurgical Applications of the Electron Microscope", organized by the Institute of Metals in November 1949, in conjunction with a number of other societies interested in the same or similar problems, served to bring together a considerable mass of information regarding the potentialities of this instrument in the metallurgical field. The symposium was perhaps the more justified in that there has been, at any rate in some quarters, a feeling of disappointment at the progress so far made. The thirteen papers are now published by the Institute of Metals as Monograph No. 8, and cover the whole field, ferrous and non-ferrous, metal powders, heat treat. ment and mechanical working.

The widespread interest in the subject is exemplified by the fact that universities, research associations and industrial laboratories in Great Britain, United States, France and Germany have all contributed. To all those concerned, either from the fundamental or technological point of view, this collection of data is to be strongly recommended. Techniques for the production of replicas are discussed; and, although what the metallurgist would most like, namely, a direct picture of the metal surface, is unfortunately not yet available, the design and construction of a reflexion electron microscope may not be long delayed.
F. C. T. 